\title{
Modelling reversibility of central European mountain lakes from acidification: Part II - the Tatra Mountains
}

\author{
Jirí Kopácek ${ }^{1}$ Bernard J. Cosby², Vladimír Majer³, Evžen Stuchlík ${ }^{4}$ and Josef Veselý3 \\ ${ }^{1}$ Hydrobiological Institute, AS CR, and Faculty of Biological Sciences, USB, Na Sádkách 7, 37005 Ceské Budejovice, Czech Republic \\ ${ }^{2}$ Department of Environmental Sciences, University of Virginia, Charlottesville, VA 22903 USA \\ ${ }^{3}$ Czech Geological Survey, Geologická 6, 15200 Praha 5, Czech Republic \\ ${ }^{4}$ Department of Hydrobiology, Charles University, Vinicná 7, 12044 Praha 2, Czech Republic
}

Email for corresponding author: jkopacek@hbu.cas.cz

\begin{abstract}
A dynamic, process-based model of surface water acidification, MAGIC7, has been applied to four representative alpine lakes in the Tatra Mountains (Slovakia and Poland). The model was calibrated for a set of 12 to 22-year experimental records of lake water composition. Surface water and soil chemistry were reconstructed from 1860 to 2002 and forecast to 2050 based on the reduction in sulphur and nitrogen emissions presupposed by the Gothenburg Protocol. Relatively small changes in the soil C:N ratios were not sufficient to simulate observed changes in $\mathrm{NO}_{3}^{-}$concentrations, so an alternative empirical approach of changes in terrestrial $\mathrm{N}$ uptake was applied. Measured sulphate sorption isotherms did not allow calibration of the pattern of sulphate response in the lakes, indicating that other mechanisms of $\mathrm{S}$ release were also important. The lake water chemistry exhibited significant changes during both the acidification advance (1860 to $1980 \mathrm{~s})$ and retreat (1980s to 2010). An increase in lake water concentrations of strong acid anions (SAA; 104-149 $\mu$ eq $1^{-1}$ ) was balanced by a decline in $\mathrm{HCO}_{3}^{-}\left(13-62 \mu \mathrm{eq} \mathrm{1^{-1 }}\right)$ and an increase in base cations $\left(\mathrm{BC} ; 42-72 \mu \mathrm{eq} \mathrm{1^{-1 }}\right), \mathrm{H}^{+}\left(0-18 \mu \mathrm{eq} \mathrm{l}^{-1}\right)$, and $\mathrm{Al}_{\mathrm{i}}^{\mathrm{n}+}\left(0-26 \mu\right.$ eq $\left.\mathrm{1}^{-1}\right)$. The carbonate buffering system was depleted in three lakes. In contrast, lake water concentrations of SAA, $\mathrm{BC}, \mathrm{H}^{+}$, and $\mathrm{Al}_{\mathrm{i}}^{\mathrm{n}}{ }^{\mathrm{n}}$ decreased by $57-82,28-42$, $0-11$, and $0-22 \mu$ eq $1^{-1}$, respectively, the carbonate buffering system was re-established, and $\mathrm{HCO}_{3}^{-}$increased by $1-21 \mu$ eq $1^{-1}$ during the chemical reversal from atmospheric acidification (by 2000). The MAGIC7 model forecasts a slight continuation in this reversal for the next decade and new steady-state conditions thereafter. Gran alkalinity should come back to 1950s levels $\left(0-71 \mu\right.$ eq $\left.1^{-1}\right)$ in all lakes after 2010. Partial recovery of the soil pool of exchangeable base cations can be expected in one catchment, while only conservation of the current conditions is predicted for three lakes. Even though the pre-industrial alkalinity values of $16-80 \mu \mathrm{eq} \mathrm{l}^{-1}$ will not be reached due to the insufficient recovery of soil quality, the ongoing chemical improvement of water should be sufficient for biological recovery of most alpine lakes in the Tatra Mountains
\end{abstract}

Keywords: MAGIC, atmospheric deposition, sulphate, nitrate, base cations, aluminium, alkalinity, pH

\section{Introduction}

The alpine ecosystem of the Tatra Mountains has been exhibiting significant recovery from acidification due to reductions in sulphur $(\mathrm{S})$ and nitrogen $(\mathrm{N})$ emission and deposition in central Europe since the late 1980s (Kopácek et al., 2001a). In contrast to other central European mountain regions (e.g. Bohemian Forest lakes; Part I, Majer et al., 2003), the Tatra lakes were not acidified so strongly that aluminium (Al) had become the dominant cation. Consequently, the current chemical reversal of waters from acidification differs in these mountains (Kopácek et al., 1998). In addition to a decline in concentrations of base cations $\left(\mathrm{BC}=\mathrm{Ca}^{2+}+\mathrm{Mg}^{2+}+\mathrm{Na}^{+}+\mathrm{K}^{+}\right)$and protons $\left(\mathrm{H}^{+}\right)$, which partly compensates for the decline in strong acid anions in both areas, a rapid decline in ionic $\mathrm{Al}$ species is the dominant compensating factor in the Bohemian Forest (Veselý et al., 1998a,b), while an increase in bicarbonate concentrations is significant in the Tatra lakes (Kopácek et al., 2002).

The recent acidification status of the Tatra lakes reflects the following two patterns: (1) pre-acidification levels of acid neutralising capacity (ANC), tightly related to $\mathrm{Ca}^{2+}$ and $\mathrm{Mg}^{2+}$ concentrations, and (2) changes in the input of strong acid anions (Kopácek et al., 2000). The latter parameter is associated with several characteristics of the lake catchments. 
Between the 1930s (Stangenberg, 1938) and the late 1980s, concentrations of sulphate $\left(\mathrm{SO}_{4}{ }^{2-}\right)$ increased by $\sim 70 \mu \mathrm{eq}{ }^{1-1}$ in all the Tatra lakes irrespective of their catchment characteristics. Nitrate $\left(\mathrm{NO}_{3}{ }^{-}\right)$concentrations, however, increased inversely to the density of catchment vegetation and soil pools by up to $>50 \mu \mathrm{eq} \mathrm{l}^{-1}$. The highest concentrations of $\mathrm{SO}_{4}^{2-}+\mathrm{NO}_{3}^{-}$, therefore, are typically found in alpine lakes situated in catchments covered predominantly with rocks and moraine and only sparse alpine meadows. Such lakes represent the alpine ecosystems which are most vulnerable to acid deposition and have (on the other hand) the highest potential for a rapid and straightforward recovery after the decline in acid deposition (Kopácek et al., 2001a). Consequently, alpine lakes are very sensitive indicators of the historical, current, and future chemical impacts on the whole mountain ecosystem.

In this Part II, MAGIC7 (Cosby et al., 2001) is applied to modelling historical changes in lake water chemistry in four sensitive catchments in the alpine zone of the Tatra Mountains. The simulation of future responses of these ecosystems to acid deposition is based on the scenario of acid emission that would result from the Gothenburg Protocol (UN-ECE, 1999).

\section{Methods}

\section{SITE DESCRIPTION}

The Tatra Mountains are situated along the Slovak-Polish border $\left(20^{\circ} 10^{\prime} \mathrm{E}, 49^{\circ} 10^{\prime} \mathrm{N}\right)$ and comprise three major ranges. The lakes selected for this study (Vyšné Wahlenbergovo, (VW); Dlugi Staw, (DS); L'adové, (LA); and Starolesnianske, (ST)) are situated in the central part (High Tatra Mountains) composed predominantly of biotite granodiorites to tonalites. The lakes were selected from a total of 116 perennial glacial lakes larger than 0.01 ha on the basis of previous studies (Kopácek and Stuchlík, 1994; Kopácek et al., 2000). LA Lake has never had negative acid neutralising capacity (ANC), while VW, DS, and ST Lakes had depleted carbonate buffering systems during the acidification peak. VW, LA, and ST Lakes are situated in the southern part of the massif, while DS is in the northern. Their major morphological characteristics are given in Table 1.

The catchments of the lakes studied lie between 1784 and $2404 \mathrm{~m}$ a.s.l., i.e. mostly above the upper tree line of dwarf pine at $\sim 1800 \mathrm{~m}$ a.s.l. Their land cover is characteristic of the Tatra alpine zone, which is, mostly, moraine or rocks (bare or covered with lichens; commonly Rhizocarpon, Acarospora oxytona and Dermatocarpon luridum) and with sparse vegetation (dry alpine meadows dominated by
Calamagrostis villosa, Festuca picta, and Luzula luzuloides). Percentage spatial coverage of alpine meadows and moraine in the catchments was estimated by using a $1: 25,000$ map, planimetry of photographs, and field observations. The lakes differ in percentage cover of their catchments with alpine meadows from $12 \%(\mathrm{VW})$ to $60 \%$ (ST) (Table 1).

\section{SOIL CHEMISTRY}

In the VW, DS, and LA catchments, soil samples were taken from all major organic and mineral horizons at four sites representative of alpine meadows and from two moraine sites in each catchment in September 2000 and 2001 (Kopácek et al., in press). Soil data on the ST catchment come from Stuchlík et al. (2002) and Kopácek (unpubl. data). The vertical and spatial heterogeneity of soil properties within a soil profile and across the whole catchment was 'homogenised' numerically to provide a catchment weighted mean (CWM) composition. The CWM soil parameters were weighted according to the spatial coverage of dominant types of land cover (alpine meadows, moraine, and solid rock) in the catchment. This catchment weighting generates a single value for each parameter, representing a hypothetical situation when all soils are distributed uniformly over the catchment. The physical and chemical characteristics of soils in the lake catchments were determined by the same methods as in Part I (Majer et al., 2003) and are described in detail by Kopácek et al. (in press).

Alpine soils (sampled in meadows) were undeveloped (mostly podsol, leptosol, cambisol, and regosol), with a negligible carbonate content. The profiles were 0.1 to $0.6 \mathrm{~m}$ deep and pools of fine soil $\left(<2 \mathrm{~mm}\right.$, dried at $\left.105^{\circ} \mathrm{C}\right)$ varied from 50 to $255 \mathrm{~kg} \mathrm{~m}^{-2}$. Soil $\mathrm{pH}$ was generally low, with the $\mathrm{pH}_{\mathrm{CaCl}}$ ranging from 3.6-4.3 in organic and from 4.1-4.8 in mineral horizons. The cation exchange capacity of alpine soils varied between 37 and $147 \mathrm{meq} \mathrm{kg}^{-1}$ ( $84 \mathrm{meq} \mathrm{kg}$ on average) and was dominated by exchangeable $\mathrm{Al}^{3+}(71 \%$ on average). The base saturation of the alpine soils was $7-45 \%$ ( $15 \%$ on average), being based primarily on exchangeable $\mathrm{Ca}^{2+}(\sim 45 \%)$, with a minor contribution of $\mathrm{Mg}^{2+}, \mathrm{Na}^{+}$, and $\mathrm{K}^{+}(13-22 \%)$. The carbon to nitrogen $(\mathrm{C}: \mathrm{N})$ ratio was within the 14-19 range in organic horizons and more variable (821) in mineral horizons.

Till soils in moraine areas were usually situated $20-60$ $\mathrm{cm}$ below the surface stones in thin (from $<1$ to $3 \mathrm{~cm}$ deep) layers or in small deposits between stones, and were found in all the moraine sites investigated. The pools of fine till soils varied between $4-33 \mathrm{~kg} \mathrm{~m}^{-2}$ with the average of $13 \mathrm{~kg}$ $\mathrm{m}^{-2}$. The till soils had $\mathrm{pH}_{\mathrm{CaCl} 2}$ values, cation exchange capacity, and base saturation comparable with alpine soils (3.9-4.4, 42-96 meq kg-1 and 7-13\%, respectively) but C:N 
Table 1. Major morphological and hydrological characteristics for the Tatra catchment-lake ecosystems, including soil parameters (Kopácek et al., in press). Lake abbreviations: VW, Vyšné Wahlenbergovo; DS, Dlugi Staw; LA, Ladové; ST, Starolesnianske.

\begin{tabular}{|c|c|c|c|c|c|}
\hline \multirow[b]{2}{*}{ Parameter } & \multirow[t]{2}{*}{ Units } & \multicolumn{3}{|c|}{ Lake } & \multirow[b]{2}{*}{$S T$} \\
\hline & & $V W$ & $D S$ & $L A$ & \\
\hline \multicolumn{6}{|l|}{ Morphology } \\
\hline Latitude (N) & WGS84 & 49.1642 & 49.2273 & 49.1841 & 49.1800 \\
\hline Longitude (E) & WGS84 & 20.0271 & 20.0107 & 20.1629 & 20.1678 \\
\hline Water level elevation & m a.s.l. & 2145 & 1784 & 2057 & 1986 \\
\hline Lake volume & $10^{3} \mathrm{~m}^{3}$ & 421 & 81 & 115 & 11 \\
\hline Maximum depth & $\mathrm{m}$ & 21.1 & 10.6 & 18 & 4.1 \\
\hline Lake area & ha & 5.0 & 1.6 & 1.7 & 0.7 \\
\hline Precipitation height & $\mathrm{m} \mathrm{yr}^{-1}$ & 1.67 & 1.59 & 1.59 & 1.42 \\
\hline Runoff & $\mathrm{m} \mathrm{yr}^{-1}$ & 1.42 & 1.35 & 1.35 & 1.21 \\
\hline Retention Time & $\mathrm{yr}$ & 0.93 & 0.09 & 0.66 & 0.41 \\
\hline \multicolumn{6}{|l|}{ Catchment Morphology } \\
\hline Catchment area (excluding lake) & ha & 27 & 63 & 11 & 1.5 \\
\hline The highest point in catchment & m a.s.l. & 2404 & 2301 & 2350 & 2030 \\
\hline Bare rock & $\%$ & 37 & 44 & 32 & 30 \\
\hline Moraine & $\%$ & 51 & 27 & 53 & 10 \\
\hline Alpine meadows & $\%$ & 12 & 29 & 15 & 60 \\
\hline \multicolumn{6}{|c|}{ Catchment Weighted Mean Soil Parameters } \\
\hline Soil depth & $\mathrm{m}$ & 0.08 & 0.11 & 0.06 & 0.29 \\
\hline Porosity ${ }^{1)}$ & $\%$ & 50 & 50 & 50 & 50 \\
\hline Bulk density ${ }^{2}$ & $\mathrm{~kg} \mathrm{~m}^{-3}$ & 263 & 289 & 456 & 345 \\
\hline Fine soil pool & $\mathrm{kg} \mathrm{m}^{-2}$ & 22 & 33 & 29 & 100 \\
\hline Cation exchange capacity & meq kg-1 & 72 & 91 & 74 & 99 \\
\hline Ca saturation & $\%$ & 3.4 & 3.4 & 11.0 & 3.7 \\
\hline $\mathrm{Mg}$ saturation & $\%$ & 1.2 & 1.4 & 2.3 & 1.6 \\
\hline Na saturation & $\%$ & 3.8 & 3.6 & 4.0 & 0.6 \\
\hline K saturation & $\%$ & 2.7 & 2.2 & 2.8 & 2.4 \\
\hline Used $\mathrm{SO}_{4}$ ads. half-saturation ${ }^{1)}$ & meq $\mathrm{m}^{-3}$ & 100 & 100 & 100 & 100 \\
\hline Measured $\mathrm{SO}_{4}$ ads. max-capacity & meq kg-1 & 2.4 & 2.8 & 2.7 & $\mathrm{ND}^{4)}$ \\
\hline Used $\mathrm{SO}_{4}$ ads. max-capacity ${ }^{\mathrm{l}}$ & meq $\mathrm{kg}^{-1}$ & 12 & 12 & 12 & 12 \\
\hline Total organic acid ${ }^{3)}$ & $\mathrm{mmol} \mathrm{m}^{-3}$ & 85 & 85 & 85 & 85 \\
\hline C pool & $\mathrm{mol} \mathrm{m}^{-2}$ & 79 & 136 & 109 & 489 \\
\hline $\mathrm{N}$ pool & $\mathrm{mol} \mathrm{m}^{-2}$ & 5.0 & 7.5 & 8.4 & 28.3 \\
\hline Average C:N of soil profile & $\mathrm{mol} \mathrm{mol}^{-1}$ & 16 & 18 & 13 & 17 \\
\hline \multicolumn{6}{|c|}{$\begin{array}{l}{ }^{1} \text { Fitted in the model calibration procedure or set (porosity). } \\
{ }^{2} \text { Not measured but recalculated from average depth and pool of fine soil. } \\
\text { 3)Estimated according to Hruška et al. (2002) for the measured soil organic content } \\
{ }^{4)} \mathrm{ND} \text {, not determined. }\end{array}$} \\
\hline
\end{tabular}

ratios (16-30) were higher. Despite their relatively low amounts, till soils represent a significant contribution to the total soil pools in the VW, DS and LA catchments due to the large proportion of moraine fields (and small area of alpine meadows) in these catchments (Table 1).

The sulphate adsorption characteristics of catchment soils were determined in batch experiments according to Alewell
(1998). Sorption experiments were conducted with fresh samples at the original soil $\mathrm{pH}$ in the $\mathrm{SO}_{4}{ }^{2-}$ concentration range of $0-100 \mu \mathrm{mol} 1^{-1}$.

The CWM pool of fine soil (alpine and moraine) was highest $\left(100 \mathrm{~kg} \mathrm{~m}^{-2}\right)$ in the ST catchment and varied between 22 and $33 \mathrm{~kg} \mathrm{~m}^{-2}$ in the other catchments. The CWM soil composition was comparable in the catchments studied, 
except for base saturation, which was $\sim$ two-fold higher in LA than in the other catchments (Table 1).

\section{LAKE WATER CHEMISTRY}

Data on water composition of the VW, LA, and ST Lakes come from Kopácek and Stuchlík (1994), Kopácek et al. (2002), and Stuchlík (unpubl. data) and data on the DS Lake from Stangenberg (1938), Henriksen et al. (1992), and Stuchlík (unpubl. data). The lakes were sampled once a year between September to October. In the 1980-1992 period, anions were determined colorimetrically and/or by capillary isotachophoresis, and base cations and Al by atomic absorption spectrophotometry and inductively coupled plasma atomic emission spectrometry. Since 1992, concentrations of major ions have been analysed by ion chromatography, and Al colorimetrically according to Driscoll (1984). The ANC has been determined by Gran titration throughout the study.

More details on the analytical methods used for lake water analyses, as well as details of the sampling before and after 1992, are given by Kopácek and Stuchlík (1994) and Kopácek et al. (2000), respectively.

\section{ATMOSPHERIC DEPOSITION}

Current bulk deposition was measured at Starolesnianske Lake (southern part; $2000 \mathrm{~m}$ a.s.1.) in the 1997-2000 period (Stuchlík et al., 2002, unpubl. data) and at Hala Gasienicowa (northern part; $1520 \mathrm{~m}$ a.s.1.) in the 1993-1998 period (Lydersen et al., 1997; The MOLAR Chemistry Group, 1999). Wet only deposition was measured at Skalnaté Pleso (southern part; $1778 \mathrm{~m}$ a.s.1.) in the 1997-2000 period (Stuchlík, unpubl. data). The long-term trend (1978-2000) in bulk deposition in northern Slovakia come from the Chopok station (Slovak Hydrometeorological Institute) situated $\sim 40 \mathrm{~km}$ south west of the Tatra Mountains at an elevation of $2008 \mathrm{~m}$.

The 1860-2000 trend in bulk deposition of $\mathrm{SO}_{4}{ }^{2-}, \mathrm{NH}_{4}^{+}$, and $\mathrm{NO}_{3}{ }^{-}$in the Tatra Mountains come from Kopácek et al. (2001a) and is based on the measured current deposition, long-term deposition trends in northern Slovakia, and S and $\mathrm{N}$ emission rates in central Europe. Trends in $\mathrm{Cl}^{-}$and $\mathrm{BC}$ deposition were the sums of their background depositions and contributions from industrial sources. The background values of $\mathrm{Cl}^{-}$and $\mathrm{BC}$ deposition (3.6 and $21 \mathrm{meq} \mathrm{m}^{-2} \mathrm{yr}^{-1}$, respectively) were set, roughly, to their bulk deposition in 1950 and equal two thirds of their current levels. The contribution of industrial sources to the total $\mathrm{Cl}^{-}$and $\mathrm{BC}$ deposition was assumed to be proportional to the $\mathrm{S}$ trend in the 1950-2010 period (Fig. 1). The calculated trends in $\mathrm{Cl}^{-}$ and $\mathrm{BC}$ deposition were closely comparable with the trends observed at the nearby Chopok station, where $\mathrm{Cl}^{-}$and $\mathrm{BC}$ declined -0.26 meq m$^{-2} \mathrm{yr}^{-1}(p<0.01)$ and -1.1 meq m$^{-2} \mathrm{yr}^{-1}$ $(p<0.05)$, respectively, in the 1978-2000 period.

The scenario of element deposition, used for the future (2000-2050) predictions, has a decreasing trend until 2010 and is then constant until 2050. The decrease in deposition of $\mathrm{S}$ and $\mathrm{N}$ compounds within the 2000-2010 period was assumed to be proportional to the decrease in their respective emission levels in the central European region (Germany, Poland, Czech Republic and Slovakia) as required by the Gothenburg Protocol (UN-ECE, 1999). This simplified approach was used, because atmospheric deposition of $\mathrm{S}$ and $\mathrm{N}$ compounds in central Europe originates predominantly (65\% to $85 \%$ ) from emissions in this region (Berge, 1997).

The respective dry deposition of $\mathrm{SO}_{4}{ }^{2-}, \mathrm{NH}_{4}^{+}$, and $\mathrm{NO}_{3}^{-}$in
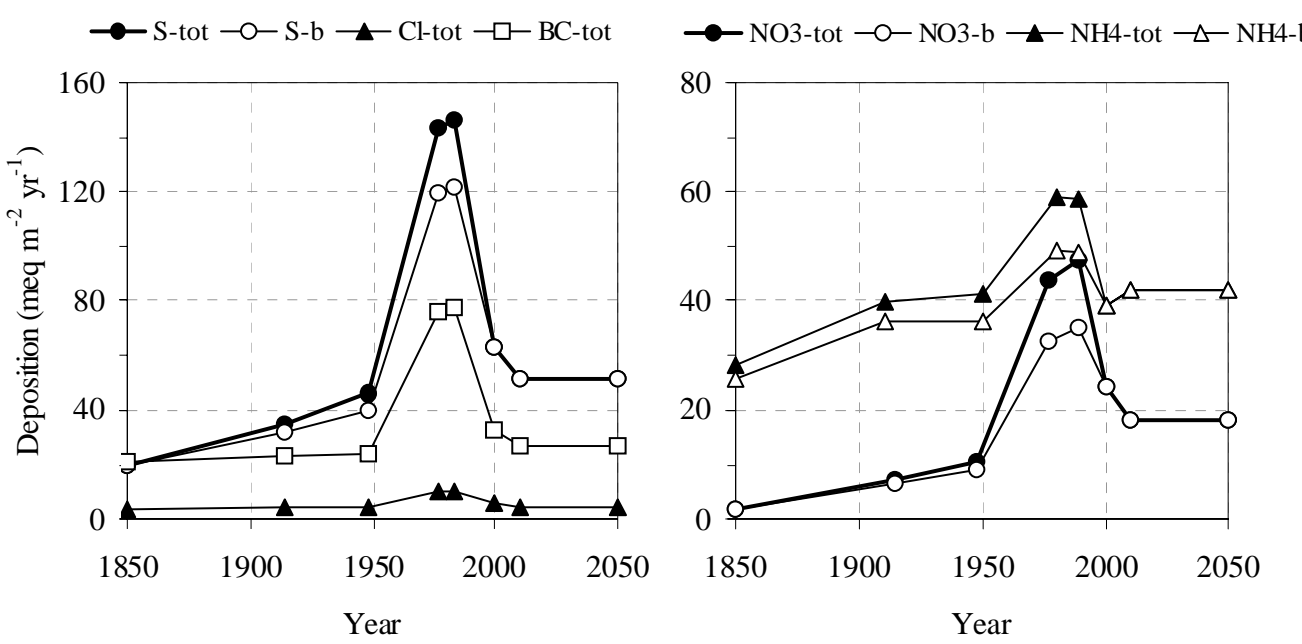

Fig. 1. Long-term trend in total (tot) and bulk (b) deposition of $\mathrm{SO}_{4}-\mathrm{S}, \mathrm{NO}_{3}-\mathrm{N}, \mathrm{NH}_{4}-\mathrm{N}, \mathrm{Cl}$, and base cations $(B C)$ in the catchments of the Tatra lakes used for MAGIC modelling. 
the Tatra Mountains (13.2, 7.1, and $11.6 \mathrm{meq} \mathrm{m}^{-2} \mathrm{yr}^{-1}$; Lydersen et al., 1997) represented $19 \%, 16 \%$, and $36 \%$ of their bulk deposition in the 1995-1996 period. These values were used to estimate trends in dry deposition factors, which varied between 1.0 and 1.2 for $\mathrm{SO}_{4}{ }^{2-}, \mathrm{NH}_{4}{ }^{+}, \mathrm{Cl}^{-}$and $\mathrm{BC}$, and between 1.0 and 1.35 for $\mathrm{NO}_{3}^{-}$. The highest dry deposition factors were applied for the 1970s and 1980s and lower values (proportionally to the bulk deposition levels) before 1970 and after 2000. Then, the total deposition was the product of bulk deposition and dry deposition factor (Fig. $1)$.

In the 2000 hydrological year, precipitation was measured at the lakes studied. The ratio between precipitation at these sites and at a reference site (Skalnaté Pleso) ranged from 0.87-1.07 (Stuchlík, unpublished data). At Skalnaté Pleso, the annual precipitation varied from 0.97 and $1.71 \mathrm{~m}$ in the 1960-2000 period, and the average of $1.31 \mathrm{~m}$ (data from Slovak Academy of Sciences) was used to estimate the average deposition in the catchments studied. The average precipitation for each catchment was estimated to increase with altitude 40 and $70 \mathrm{~mm}$ per $100 \mathrm{~m}$ of elevation in the southern and northern part of the mountain range, respectively (Chomitz and Šamaj, 1974). The specific outflow was assumed to represent $85 \%$ of estimated precipitation (Lajczak, 1996). The resulting data (Table 1) were used as constants for the whole 1860-2050 period.

\section{Results and discussion}

\section{MODEL CALIBRATION}

The MAGIC (version 7) model by Cosby et al. (2001) was calibrated using the average atmospheric deposition for the 1997-2000 period, lake water chemistry for the 1980-2002 (VW and LA) 1984-2002 (ST) and 1990-2002 (DS) periods, and soil chemistry for the year 2000 (Tables 1 and 2). The calibrations at each site were effected as follows:

\section{Fixed parameters}

Dissociation constants of tri-protic organic acids, the $\mathrm{Al}(\mathrm{OH})_{3}$ solubility, and stability constants of organic-Al complexes (K(AlA) and $\mathrm{K}\left(\mathrm{AlHA}^{+}\right)$) were set the same as for the Bohemian Forest lakes (Part I, Majer et al., 2003), where the modelled concentrations reasonably equalled the measured concentrations of ionic and organic $\mathrm{Al}$ forms and organic acid anions (Table 3).

Table 2. The average (1997-2000) composition of the Tatra lakes, wet-only deposition at Skalnaté Pleso, and bulk deposition at Starolesnianske Lake and the used data on in-lake removal of $\mathrm{SO}_{4}{ }^{2-}$ and $\mathrm{NO}_{3}{ }_{3}^{-}$(in parentheses: data calculated according to Kelly et al., 1987). Data come from Kopácek et al. (2002) and Stuchlík (unpublished data). For lake abbreviations see legend to Table 1 .

\begin{tabular}{|c|c|c|c|c|c|c|c|}
\hline \multirow[b]{2}{*}{ Parameter } & \multirow[t]{2}{*}{ Units } & \multicolumn{4}{|c|}{ Lake } & \multirow{2}{*}{$\begin{array}{l}\text { Wet } \\
\text { deposition }\end{array}$} & \multirow{2}{*}{$\begin{array}{l}\text { Bulk } \\
\text { deposition }\end{array}$} \\
\hline & & $V W$ & $D S$ & $L A$ & $S T$ & & \\
\hline \multicolumn{8}{|c|}{ Concentration } \\
\hline $\mathrm{Ca}^{2+}$ & $\mu$ eq $1^{-1}$ & 82.7 & 89.9 & 110.1 & 29.4 & 10.7 & 14.9 \\
\hline $\mathrm{Mg}^{2+}$ & $\mu$ eq $1^{-1}$ & 8.0 & 8.1 & 6.8 & 6.3 & 2.6 & 3.4 \\
\hline $\mathrm{Na}^{+}$ & $\mu \mathrm{eq} \mathrm{l}^{-1}$ & 8.7 & 15.3 & 10.6 & 9.5 & 2.7 & 6.9 \\
\hline $\mathrm{K}^{+}$ & $\mu$ eq $\mathrm{l}^{-1}$ & 1.7 & 2.8 & 1.7 & 3.9 & 1.8 & 3.7 \\
\hline $\mathrm{NH}_{4}^{+}$ & $\mu$ eq $1^{-1}$ & 0.8 & 1.5 & 1.6 & 1.8 & 22.9 & 34.7 \\
\hline $\mathrm{SO}_{4}^{2-}$ & $\mu$ eq $1^{-1}$ & 37.4 & 52.4 & 34.8 & 43.2 & 45.4 & 55.6 \\
\hline $\mathrm{Cl}^{-}$ & $\mu \mathrm{eq} \mathrm{l}^{-1}$ & 4.4 & 3.8 & 3.8 & 3.5 & 3.5 & 7.5 \\
\hline $\mathrm{NO}_{3}^{-}$ & $\mu$ eq $1^{-1}$ & 28.9 & 35.0 & 23.5 & 3.9 & 16.9 & 21.0 \\
\hline $\mathrm{F}^{-3}$ & $\mu \mathrm{eq} \mathrm{l}^{-1}$ & 0.6 & 1.2 & 0.6 & 0.4 & $<1.0$ & $<1.0$ \\
\hline $\mathrm{pH}$ & & 6.20 & 6.11 & 6.57 & 5.27 & 4.58 & 4.68 \\
\hline $\mathrm{Al}_{\mathrm{T}}$ & $\mu \mathrm{mol} \mathrm{1} \mathrm{l}^{-1}$ & 0.03 & 0.07 & 0.03 & 0.95 & $<0.01$ & $<0.01$ \\
\hline DOC & $\mu \mathrm{mol} \mathrm{l} \mathrm{l}^{-1}$ & 14.0 & 15.9 & 11.7 & 103 & $120 *$ & $80 *$ \\
\hline $\mathrm{ANC}$ & $\mu$ eq $1^{-1}$ & 26 & 21 & 67 & -2 & -23 & -18 \\
\hline \multicolumn{8}{|c|}{ In-lake removal } \\
\hline $\mathrm{SO}_{4}-\sin \mathrm{k}$ & $\%$ & $15(3)$ & $1.1(0.3)$ & $30(4)$ & $15(14)$ & & \\
\hline $\mathrm{NO}_{3}-\operatorname{sink}$ & $\%$ & $19(19)$ & $3(3)$ & $25(25)$ & $65(62)$ & & \\
\hline
\end{tabular}


Table 3. Fixed parameters (measured* or estimated) for the Tatra lakes and catchment soils used in calibration of MAGIC 7. For lake abbreviations see legend to Table 1 .

\begin{tabular}{|c|c|c|c|}
\hline Parameter & $\begin{array}{l}\text { For water } \\
\text { or soil }\end{array}$ & Units & All lakes \\
\hline \multirow[t]{2}{*}{ Temperature* } & water & ${ }^{\circ} \mathrm{C}$ & $3.0(2.0$ in $\mathrm{ST})$ \\
\hline & soil & ${ }^{\circ} \mathrm{C}$ & $2.5(2.0$ in $\mathrm{ST})$ \\
\hline \multirow{2}{*}{$\mathrm{CO}_{2}$ partial pressure } & water & $\%$ & $0.04-0.07$ \\
\hline & soil & $\%$ & $0.38-0.39$ \\
\hline pK & soil and water & $-\log$ & 2.6 \\
\hline $\mathrm{pK}_{2}$ (organic acids) & soil & $-\log$ & 5.66 \\
\hline $\mathrm{pK}_{2}$ (organic acids) & water & $-\log$ & 5.8 \\
\hline $\mathrm{pK}_{3}$ (organic acids) & soil & $-\log$ & 5.94 \\
\hline $\mathrm{pK}_{3}$ (organic acids) & water & $-\log$ & 7.0 \\
\hline Solubility $\mathrm{Al}(\mathrm{OH})_{3}$ & soil and water & $\log$ & 9.0 \\
\hline $\mathrm{K}(\mathrm{AlA})$ & water & $\log$ & 8.5 \\
\hline $\mathrm{K}\left(\mathrm{AlHA}^{+}\right)$ & water & $\log$ & 10.0 \\
\hline
\end{tabular}

\section{Deposition trends}

Trends in the total deposition of $\mathrm{SO}_{4}^{2-}, \mathrm{Cl}^{-}, \mathrm{NO}_{3}^{-}, \mathrm{NH}_{4}^{+}$, and $\mathrm{BC}$ into the catchments were applied as shown in Fig. 1. At the beginning of the Industrial Revolution, reduced nitrogen compounds dominated the sum of emitted and deposited $\mathrm{S}$ and $\mathrm{N}$ compounds in central Europe. While the estimated total deposition of $\mathrm{SO}_{4}{ }^{2-}$ and $\mathrm{NO}_{3}{ }^{-}$was $<20$ and $<2$ meq m${ }^{-}$ ${ }^{2} \mathrm{yr}^{-1}$, respectively, in the Tatra Mountains, the estimated $\mathrm{NH}_{4}^{+}$deposition was $\sim 30 \mathrm{meq} \mathrm{m}^{-2} \mathrm{yr}^{-1}$ in the 1860 s (Fig. 1). This value was estimated on the basis of long-range $\mathrm{NH}_{3}$ transport. The real deposition of $\mathrm{NH}_{4}^{+}$, however, could be even higher before the 1950s due to an additional local source of ammonia emission, originating from keeping sheep and cattle in pasture in some areas of the alpine zone.

The sheep pasturing was most intensive in the beginning of the 19th century, then declined continuously from the middle of 19th century, and was forbidden after 1949 and 1955 when the Tatra Mountains were designated as a national park in Slovakia and Poland, respectively (Vološcuk, 1994). Consequently, the contribution of the local emission source of ammonia to the total $\mathrm{NH}_{4}^{+}$deposition in the area probably decreased from 1800 to 1950 . Such a trend suggests that the real $\mathrm{NH}_{4}^{+}$deposition in the Tatra Mountains could be even more stable before 1950 than shown in Fig. 1.

Atmospheric inputs of $\mathrm{SO}_{4}{ }^{2-}$ and $\mathrm{NO}_{3}{ }^{-}$increased steadily until the late 1950 s and then very sharply until the 1980 s to the respective maximums of 120 and $35 \mathrm{meq} \mathrm{m}^{-2} \mathrm{yr}^{-1}$ for bulk and 145 and $47 \mathrm{meq} \mathrm{m}^{-2} \mathrm{yr}^{-1}$ for total deposition. The increase in $\mathrm{NH}_{4}^{+}$deposition was gentler than that of $\mathrm{NO}_{3}{ }^{-}$ after 1950 but $\mathrm{NH}_{4}-\mathrm{N}$ dominated the pool of dissolved inorganic nitrogen $\left(\mathrm{DIN}=\mathrm{NO}_{3}-\mathrm{N}+\mathrm{NH}_{4}-\mathrm{N}\right)$ deposition throughout the study period (Fig. 1). The total DIN deposition and the $\mathrm{NO}_{3}-\mathrm{N}: \mathrm{NH}_{4}-\mathrm{N}$ ratio increased two- and three-fold, respectively, between the 1950s and 1980s.

During the 1990s, atmospheric inputs of $\mathrm{S}$ and DIN decreased by $57 \%$ and $\sim 35 \%$ to 62 and $67 \mathrm{meq} \mathrm{m}^{-2} \mathrm{yr}^{-1}$, respectively, in the year 2000. The expected deposition of $\mathrm{SO}_{4}{ }^{2-}$ and $\mathrm{NO}_{3}{ }^{-}$in 2010 (51 and $18 \mathrm{meq} \mathrm{m}^{-2} \mathrm{yr}^{-1}$, respectively), resulting from the target emissions of $\mathrm{S}$ and oxidised N compounds (Gothenburg Protocol; UN-ECE, 1999) in the central Europe, should bring only small additional improvements of air quality in the Tatra Mountains (Fig. 1). In contrast, the current emission rate of $\mathrm{NH}_{3}$ in central Europe is lower than the 2010 target and the future scenario of $\mathrm{NH}_{4}^{+}$deposition is a slight increase (up to $\sim 45$ meq $\mathrm{m}^{-2} \mathrm{yr}^{-1}$ ). Around 2010, the $\mathrm{SO}_{4}{ }^{2-}, \mathrm{NH}_{4}^{+}$, and $\mathrm{NO}_{3}{ }^{-}$ deposition in the Tatra Mountains could reach levels comparable to those in the 1950s (Fig. 1).

\section{Sulphur dynamics in soils}

The $\mathrm{SO}_{4}{ }^{2-}$ adsorption half saturation and maximum adsorption capacity varied from 3.2 to $5.2 \mathrm{meq} \mathrm{m}^{-3}$ and from 2.4 to $2.8 \mathrm{meq} \mathrm{kg}^{-1}$, respectively. These original data did not allow the satisfactory calibration of the model because the adsorption maxima were too low (and the $\mathrm{SO}_{4}{ }^{2-}$ adsorption half saturations too high) for the model to predict properly the observed delay between $\mathrm{SO}_{4}{ }^{2-}$ deposition and in-lake concentrations during both the acidification progress and retreat (i.e. the data distribution along the time axis). Consequently, soil sulphate chemistry was fitted in the calibration procedure such that modelled concentration equalled the measured in-lake concentrations of $\mathrm{SO}_{4}^{2-}$ in the $1980 \mathrm{~s}$ and $1990 \mathrm{~s}$. The fitted values of $\mathrm{SO}_{4}{ }^{2-}$ maximum adsorption capacity, which reasonably simulated the observed trends in lake water chemistry, were $\sim$ four to fivefold higher (12 meq $\mathrm{kg}^{-1}$ ) than the measured adsorption data (Table 1). Such a pattern suggests that some alternative mechanism paralleled the physical adsorption of $\mathrm{SO}_{4}{ }^{2-}$ on $\mathrm{Fe}$ and $\mathrm{Al}$ oxides and contributed to the $\mathrm{S}$ immobilisation in soils. Tight relationships between concentrations of total $\mathrm{S}$ and organic $\mathrm{C}$ in the Tatra soils $(\mathrm{P}<0.001)$ suggest the dominant importance of soil organic matter in $\mathrm{S}$ retention and release, as is also observed elsewhere (e.g. Torssander and Mörth, 1998). The fitted values of $\mathrm{SO}_{4}{ }^{2-}$ maximum adsorption capacity were two to three-fold lower in alpine soils than in the Bohemian Forest (Majer et al., 2003). This difference was in agreement with lower CWM concentrations of organic $\mathrm{C}$ in alpine than in forest soils $(\sim 4$ v. 6-10 mol $\left.\mathrm{kg}^{-1}\right)$.

Because the exchangeable soil $\mathrm{SO}_{4}{ }^{2-}$ pool is also supplied 
by mineralisation of organically bound $\mathrm{S}$ (Novák et al., 1996), the S wash out from soils could not simply follow the sulphate sorption isotherms but could be subjected to mineralisation rate of soil organic matter.

\section{Nitrogen dynamics in soils}

Nitrogen leaching to surface water depends on the difference between $\mathrm{N}$ input via deposition and its uptake by plants, denitrification loss, and net immobilisation in the soil (Cosby et al., 2001). Net immobilisation of soil $\mathrm{N}$ in the model is assumed to be governed by the $\mathrm{C}: \mathrm{N}$ ratio. The $\mathrm{CWM}$ values of $\mathrm{C}: \mathrm{N}$ ratios in the catchments varied between 13 (LA) and 18 (DS) in 2000. Hypothetical soil C: $\mathrm{N}$ ratios were probably only slightly higher in the 1930s, as estimated from the present soil composition and cumulative $\mathrm{N}$ deposition and outflow (Kopácek et al., 2001a). They were $\leq 20$, i.e. significantly less than 25 , which is the threshold of potential risk of elevated $\mathrm{NO}_{3}{ }^{-}$leaching from forest soils (Gundersen et al., 1998a). This indicates a limited capacity of the Tatra soils to assimilate the elevated atmospheric $\mathrm{N}$ deposition after the 1950s (Fig. 1). There are no direct data to evaluate historical changes in the ability of the Tatra catchments to immobilise or lose $\mathrm{N}$ (e.g., historical records on plant uptake of $\mathrm{N}$ or mineralisation rate of soil organic $\mathrm{N}$ pools). Nevertheless, they can be deduced from the observed changes in lake water chemistry.

The estimated changes in the soil C:N ratios in the Tatra catchments did not allow the model to simulate the observed sharp increase and decrease in lake water concentrations of $\mathrm{NO}_{3}^{-}$. Instead, an alternative empirical approach, which would enable the simulation of the observed temporal variations and the current spatial distribution of $\mathrm{NO}_{3}^{-}$ concentrations in the lakes, was sought. This is described as follows:

(1) Temporal changes: In 1937, Stangenberg (1938) found only low $\mathrm{NO}_{3}{ }^{-}$concentrations $\left(0-4 \mu \mathrm{eq}^{-1}\right)$ in 16 , mostly alpine, Tatra lakes. Estimated total deposition of DIN varied between 30 and $50 \mathrm{meq} \mathrm{m}^{-2} \mathrm{yr}^{-1}$ (i.e. $4-7 \mathrm{~kg}$ $\mathrm{ha}^{-1} \mathrm{yr}^{-1}$ ) during the $1850-1950$ period (Fig. 1). The low $\mathrm{NO}_{3}^{-}$leaching suggests steady-state conditions in DIN dose and loss (nearly complete immobilisation of DIN deposition) within catchment-lake ecosystems. In the 1980s, the highest in-lake $\mathrm{NO}_{3}^{-}$concentrations were as high as $56 \mu \mathrm{eq}^{-1}$ in some alpine lakes and were only slightly less than DIN concentrations in precipitation (Kopácek et al., 1996). This pattern suggested a very low ability of catchments to immobilise N. Most of the deposited $\mathrm{NH}_{4}{ }^{+}$was probably only nitrified and leached, or alternatively, an equivalent amount of $\mathrm{NO}_{3}{ }^{-}$originated from the internal soil sources (mineralisation of organic
$\mathrm{N}$, followed by nitrification). Total DIN deposition was $\sim 100 \mathrm{meq} \mathrm{m}^{-2} \mathrm{yr}^{-1}$ in the $1980 \mathrm{~s}$ (Fig. 1) and the estimated DIN retention was $<20 \mathrm{meq} \mathrm{m}^{-2} \mathrm{yr}^{-1}$ (i.e. $<20 \%$ of DIN deposition), as shown for two alpine Tatra catchments (Kopácek et al., 2001a). Consequently, on the basis of historical records on lake water composition, it can be deduced that the current ability of the Tatra catchments to immobilise $\mathrm{N}$ is lower than in the pre-industrial era.

(2) Land cover effect: Current concentrations of $\mathrm{NO}_{3}^{-}$in alpine lakes exhibit great variability with respect to their catchment characteristics (Kopácek et al., 2000), increasing inversely with catchment coverage by soil and vegetation (Fig. 2). Consequently, the catchment characteristics govern current $\mathrm{NO}_{3}^{-}$leaching.

In the model, net catchment retention of $\mathrm{N}$ was set roughly as a function of time and catchment characteristics as follows: (i) For the 1860-1950 period, 100\% uptake of $\mathrm{NO}_{3}-\mathrm{N}$ was assumed only in the part of catchment covered with meadows and $100 \%$ uptake of $\mathrm{NH}_{4}-\mathrm{N}$ was assumed in the whole catchment. The only DIN entering the lake was equal to $\mathrm{NO}_{3}$ $\mathrm{N}$ deposition on rocks and moraine. (ii) For the 1950-2050 period, $100 \%$ uptake of $\mathrm{NH}_{4}-\mathrm{N}$ and $\mathrm{NO}_{3}-\mathrm{N}$ was assumed only in the part of the catchment covered with meadows. The $\mathrm{NO}_{3}{ }^{-}$entering the lake originated from $\mathrm{NO}_{3}-\mathrm{N}^{-}$and $\mathrm{NH}_{4}{ }^{-}$ $\mathrm{N}$ deposition on the rocky and moraine areas. It was assumed that all $\mathrm{NH}_{4}-\mathrm{N}$ deposited to these parts of the catchment was

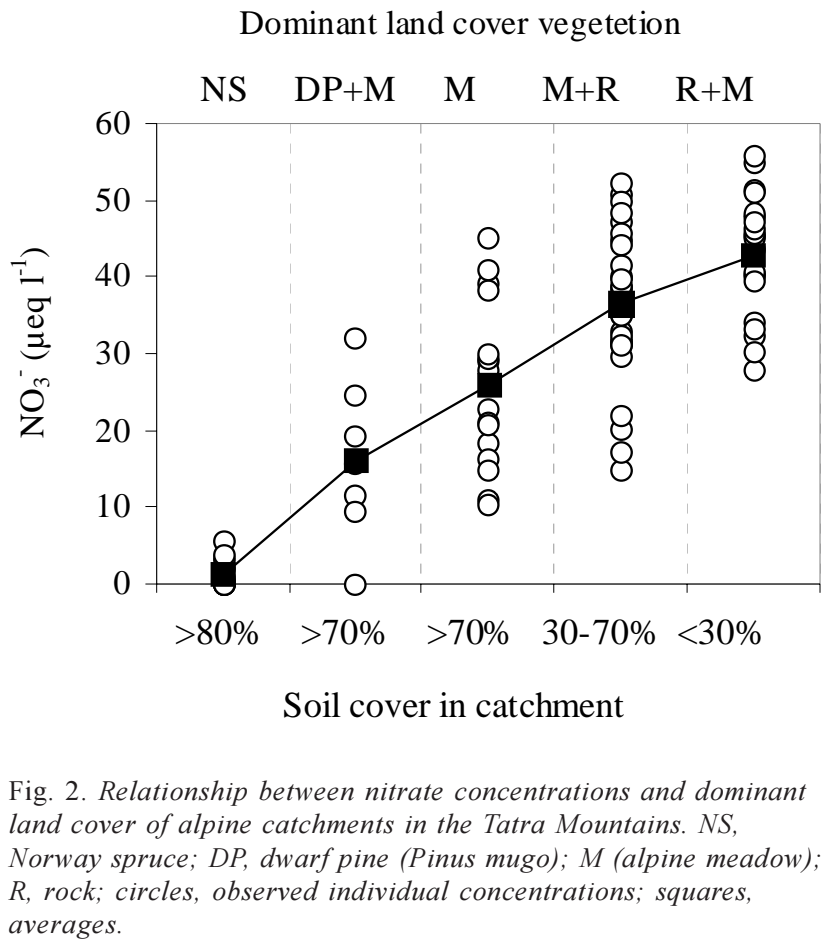


adsorbed rapidly, and nitrified but not accumulated. Such an approach can be justified by the fact that $\mathrm{NH}_{4}^{+}$ concentrations $<3 \mu$ eq $1^{-1}$ were usually found in the alpine lakes. The exceptions were rocky lakes during snowmelt, when $\mathrm{NH}_{4}^{+}$concentrations up to $9 \mu \mathrm{eq} \mathrm{l}^{-1}$ were observed (Kopácek et al., 1996).

It should be emphasised that the above changes in the catchment ability to assimilate DIN were set empirically to simulate the observed trends in the in-lake $\mathrm{NO}_{3}{ }^{-}$ concentrations. At present, there are no simple explanations for the possible soil processes which could govern such changes. The elevated terrestrial $\mathrm{NO}_{3}^{-}$export may be associated with a decreased ability of the catchments to assimilate $\mathrm{N}$ (e.g. acidification-derived lowering of microbial immobilisation of $\mathrm{NO}_{3}^{-}$), or with changes in the mineralisation rate of soil organic $\mathrm{N}$ due to the rapidly elevated DIN deposition in the 1950s. Similar fast responses in $\mathrm{NO}_{3}^{-}$leaching to $\mathrm{N}$ addition or removal have been observed elsewhere (e.g. Gundersen et al., 1998b). Another factor that deserves consideration is the historical change in land-use. Grazing contributes significantly to the net removal of $\mathrm{N}$ from ecosystems (Glatzel, 1991). The end of grazing in the early 1950s coincided with the rapid increase in atmospheric deposition of DIN (Fig. 1). After a long period of steady-state conditions in the $\mathrm{N}$ budget, these two opposing effects caused a rapid change in the net $\mathrm{N}$ supply of soils. Consequently, the empirically set DIN retention in the model represents the net result of processes reducing sinks and/or elevating internal sources of $\mathrm{N}$ in the Tatra soils, starting at the beginning of the 1950s.

\section{In-lake retention of nitrate and sulphate}

Net annual removal of $\mathrm{SO}_{4}{ }^{2-}$ and $\mathrm{NO}_{3}{ }^{-}$in the lakes (Table 2) was estimated from their loading according to Kelly et al. (1987). In these calculations, mass transfer coefficients were set at 0.54 and $5.0 \mathrm{~m} \mathrm{yr}^{-1}$ (Kelly et al., 1987; Curtis et al., 1998) for $\mathrm{SO}_{4}{ }^{2-}$ and $\mathrm{NO}_{3}{ }^{-}$, respectively. Because the bottoms of some lakes are partly covered with rocks and big boulders, the above results were reduced proportionally to the percentage of the bottom covered with sediment. The area of sediment was estimated at the lakes, and was set between 30 and $100 \%$ of the lake area. Thus, estimated values of inlake removal of $\mathrm{NO}_{3}^{-}$(3-60\% of the $\mathrm{NO}_{3}{ }^{-}$loading) allowed a reasonable simulation of the current concentrations in most of the lakes and were applied for the whole study period.

In contrast to $\mathrm{NO}_{3}^{-}$, the estimated values of in-lake removal of $\mathrm{SO}_{4}{ }^{2-}$ were too low to model, satisfactorily, maxima in $\mathrm{SO}_{4}{ }^{2-}$ concentrations in the $1980 \mathrm{~s}$, as well the current lowered concentrations (i.e. the data distribution along the concentration axis). This disproportion was lowest in the drainage DS and ST Lakes but significant in the seepage
VW and LA Lakes, where five to seven-fold higher values of in-lake $\mathrm{SO}_{4}^{2-}$ removal were fitted during the model calibration (Table 2). This disproportion could be in part due to higher mass transfer coefficients of $\mathrm{SO}_{4}{ }^{2-}$ in seepage lakes, where ionic fluxes into sediments may be higher than those based on diffusion only. Moreover, the fitted values of in-lake $\mathrm{SO}_{4}{ }^{2-}$ removal represent a correction for uncertainties associated with $\mathrm{S}$ dynamics within the whole catchment-lake ecosystems. It was assumed that the fitted percent in-lake removal of $\mathrm{SO}_{4}^{2-}$ was stable throughout the study period.

\section{Calibrated parameters}

Weathering rates, cation-exchange selectivity coefficients for base cations, and the original base saturation of soils were determined by a trial-and-error procedure such that the modelled pools and concentrations equalled the measured soil exchange pools and lake chemistry concentrations of each base cation for the 1997-2000 period. This step was performed using an automated optimisation routine and the results are given in Table 4.

\section{MODELLED VERSUS OBSERVED LAKE WATER COMPOSITION}

Simulated trends in $\mathrm{SO}_{4}{ }^{2-}$ concentrations in the Tatra alpine lakes increased (paralleling $\mathrm{S}$ deposition) from their background level of 11-16 $\mu \mathrm{eq}^{-1}$ in the middle of 19th century to a maximum of $92-109 \mu \mathrm{eq} \mathrm{l}^{-1}$ in the $1980 \mathrm{~s}$, and

Table 4. Calibrated parameters for the Tatra lakes obtained from MAGIC 7. For lake abbreviations see legend to Table 1.

\begin{tabular}{|c|c|c|c|c|c|}
\hline & \multirow[t]{2}{*}{ Units } & \multicolumn{4}{|c|}{ Lake } \\
\hline & & $V W$ & $D S$ & $L A$ & $S T$ \\
\hline \multicolumn{6}{|c|}{ Cation exchange selectivity coefficients } \\
\hline $\mathrm{Al}-\mathrm{Ca}$ & $\log$ & 1.09 & 1.05 & 0.35 & -0.37 \\
\hline $\mathrm{Al}-\mathrm{Mg}$ & $\log$ & -0.94 & -1.01 & -1.33 & -1.46 \\
\hline $\mathrm{Al}-\mathrm{Na}$ & $\log$ & -6.00 & -5.66 & -5.53 & -3.19 \\
\hline Al-K & $\log$ & -7.51 & -6.81 & -7.18 & -7.50 \\
\hline \multicolumn{6}{|c|}{ Weathering rates } \\
\hline $\mathrm{Ca}^{2+}$ & meq $\mathrm{m}^{-2} \mathrm{yr}^{-1}$ & 97 & 89 & 120 & 33 \\
\hline $\mathrm{Mg}^{2+}$ & meq $\mathrm{m}^{-2} \mathrm{yr}^{-1}$ & 5.4 & 5.8 & 4.4 & 4.9 \\
\hline $\mathrm{Na}^{+}$ & meq $\mathrm{m}^{-2} \mathrm{yr}^{-1}$ & 4.0 & 5.7 & 6.2 & 8.4 \\
\hline $\mathrm{K}^{+}$ & meq $\mathrm{m}^{-2} \mathrm{yr}^{-1}$ & 0.1 & 0.9 & 0.3 & 0.2 \\
\hline \multicolumn{6}{|c|}{ Initial base saturation (1860) } \\
\hline $\mathrm{Ca}$ & $\%$ & 5.8 & 6.0 & 21.2 & 4.4 \\
\hline $\mathrm{Mg}$ & $\%$ & 2.0 & 2.4 & 4.1 & 1.7 \\
\hline $\mathrm{Na}$ & $\%$ & 3.8 & 3.7 & 4.4 & 0.6 \\
\hline $\mathrm{K}$ & $\%$ & 2.1 & 2.0 & 2.5 & 1.9 \\
\hline
\end{tabular}


then decreased to the current concentrations of 36-47 $\mu$ eq $\mathrm{l}^{-}$ 1. The modelled trends predict an additional slow decrease in $\mathrm{SO}_{4}{ }^{2-}$ concentrations by the late 2010 s, after which they should level off at 27-39 $\mu$ eq $\mathrm{l}^{-1}$ (Fig. 3).

Similarly, concentrations of $\mathrm{Cl}^{-}$increased significantly from their background concentrations of $\sim 3 \mu \mathrm{eq} \mathrm{l}^{-1}$ to maximum values of 7-8 $\mu$ eq $1^{-1}$ in the 1980 s. After the rapid decrease in the $1990 \mathrm{~s}$, concentrations of $\mathrm{Cl}^{-}$should stabilise at 3-4 $\mu$ eq $\mathrm{l}^{-1}$ by 2010 .

The modelled data on $\mathrm{NO}_{3}{ }^{-}$differed from $\mathrm{SO}_{4}{ }^{2-}$ and $\mathrm{Cl}^{-}$in
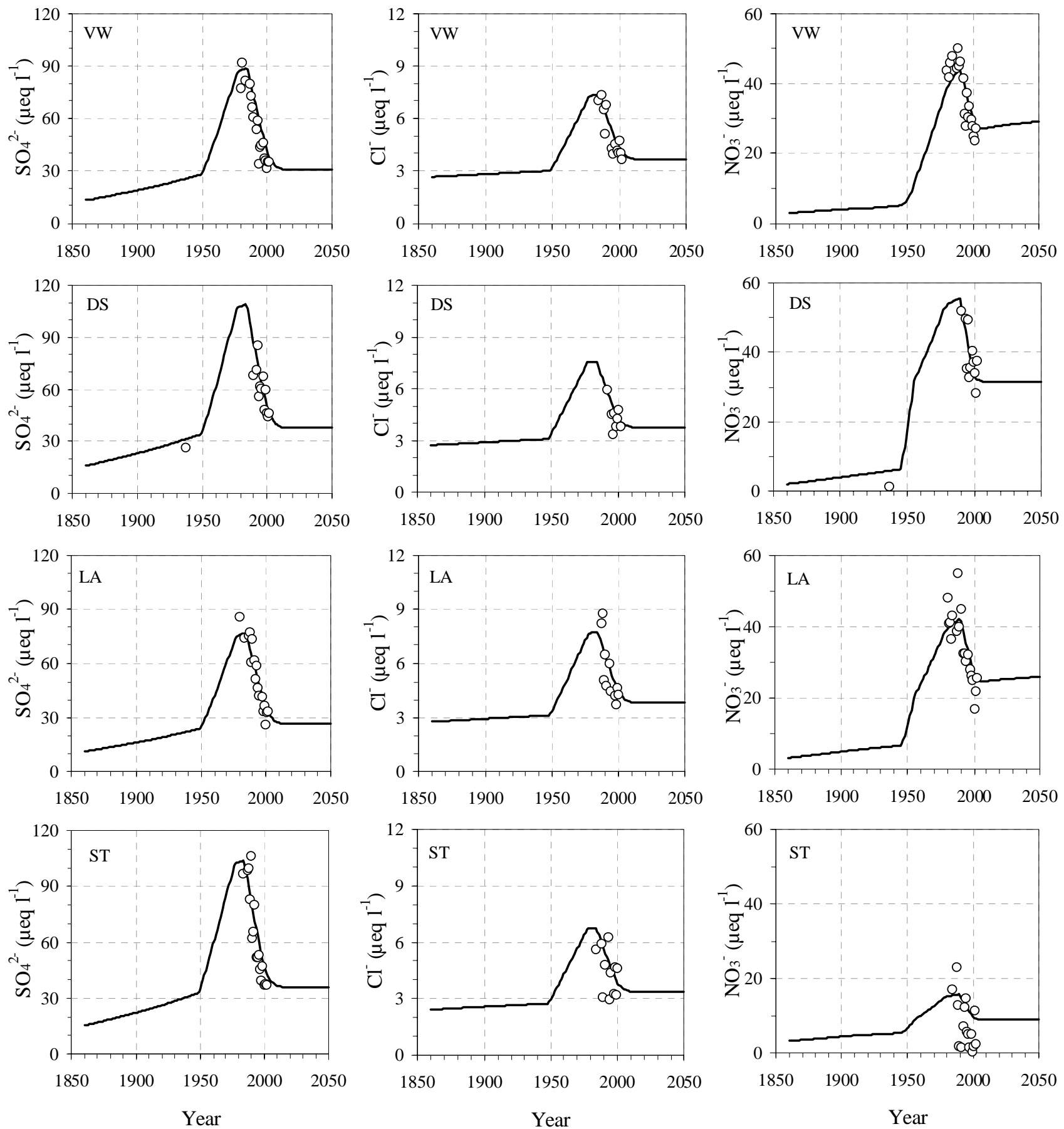

Fig. 3. Measured (open circles) and modelled (line; MAGIC 7) trends in strong acid anions in alpine lakes in the Tatra Mountains. Forecast is based on quality of atmospheric deposition presupposed by the Gothenburg Protocol (UN-ECE, 1999). For lake abbreviations see legend to Table 1 . 
two major aspects: (1) a substantially larger range of $\mathrm{NO}_{3}^{-}$ concentrations in the lakes due to differing abilities of their catchments to retain N (Fig. 2) and (2) larger uncertainty associated with the future predictions. Concentrations of $\mathrm{NO}_{3}{ }^{-}$were low in the lakes until the $1950 \mathrm{~s}$, and then rapidly increased to $15-54 \mu \mathrm{eq} \mathrm{l}^{-1}$ in the late $1980 \mathrm{~s}$. The current $\mathrm{NO}_{3}{ }^{-}$concentrations have decreased to $<33 \mu \mathrm{eq} \mathrm{l}^{-1}$ and the model predicts an additional small decrease in $\mathrm{NO}_{3}{ }^{-}$ concentrations by 2010. A slow increase in $\mathrm{NO}_{3}^{-}$can be expected after 2010, if $\mathrm{NH}_{4}^{+}$emission in central Europe increases (Fig. 1) according to the Gothenburg Protocol (UNECE, 1999). However, such an increase will have to be based on increasing agricultural production in the area of Poland, Slovakia and the Czech Republic, which is unlikely considering the economic prognosis in these EU associated countries. More probably, agricultural production will continue to decline slightly for a few years and then stabilise. This makes the 2010 level of $\mathrm{NO}_{3}^{-}$concentrations more realistic than those of 2050 .

The above prognoses were based on the assumption that no significant change will occur in the ability of the alpine ecosystem to retain $\mathrm{N}$. The higher predicted versus observed data in recent years (Fig. 3), however, suggest that the ecosystem ability to immobilise $\mathrm{N}$ has probably increased compared to the previous decades. The change may be associated with both terrestrial and aquatic processes. Catchment assimilation of $\mathrm{N}$ could increase slightly with acidification retreat, as in the Bohemian Forest (Majer et al., 2003). The reasons for such a change is unclear, but may be associated either with the decline in DIN deposition (inversely to the increased $\mathrm{NO}_{3}^{-}$leaching in the 1950s), or with the recent warming in central Europe (Weber et al., 1997). Climate may be a primary factor controlling the catchment $\mathrm{NO}_{3}^{-}$production scheme. The average annual temperature increase of $>1{ }^{\circ} \mathrm{C}$ over the last 15 years could prolong the growing season by $\sim 3$ weeks (Zhou et al., 2001), increase $\mathrm{N}$ assimilation, and reduce the $\mathrm{NO}_{3}{ }^{-}$leaching. The respective average pools of soil organic $\mathrm{N}$ and $\mathrm{N}$ in soil microbial biomass are 41 and $0.86 \mathrm{~mol} \mathrm{~m}^{-2}$ in alpine meadows and 2 and $0.04 \mathrm{~mol} \mathrm{~m}^{-2}$ in moraine areas of the Tatra Mountains (Kopácek et al., in press). This means that the pool of $\mathrm{N}$ in the soil microbial biomass, even in moraine areas (with very limited soils), is comparable to the annual atmospheric deposition of DIN (Fig. 1). Consequently, climatically- or chemically-derived changes in soil N-cycling can have a more significant impact on future $\mathrm{NO}_{3}^{-}$leaching than the expected changes in DIN deposition.

An elevated in-lake assimilation of $\mathrm{N}$ could be caused by increased biological activity resulting from an increase in air temperature (Sommaruga-Wögrath et al., 1997) or by a lower Al-induced immobilisation of phosphorus. Phosphorus is the dominant element controlling phytoplankton production in the lakes, and is partly immobilised by adsorption on (or complexation with) Al hydroxides in both water column and sediments (Kopácek et al., 2001b). This process may be xpected to cease due to the increasing $\mathrm{pH}$ and decreasing terrestrial export of $\mathrm{Al}$ (see later). The increased biological productivity of the lakes studied is suggested by increasing concentrations of chlorophyll-a (Stuchlík, unpublished data) in VW and DS Lakes. In ST Lake, concentrations of phosphorus and chlorophyll-a are the highest among the alpine Tatra lakes (Kopácek, et al., 2000). The most pronounced assimilative uptake of N in ST Lake probably contributes to the biggest disproportion between the predicted and currently observed $\mathrm{NO}_{3}{ }^{-}$ concentrations among the lakes studied (Fig. 3).

The modelled values of Gran alkalinity and $\mathrm{pH}$ were 16$80 \mu \mathrm{eq} 1^{-1}$ and 6.2-6.8, respectively, in 1860. The lowest pre-industrial $\mathrm{pH}$ and Gran alkalinity were in ST Lake with a predominantly meadow catchment (Table 1) and the highest input of organic matter from terrestrial sources. The concentration of dissolved organic carbon (DOC) is one order of magnitude higher in ST than in the other lakes (Table 2), representing a significant source of organic acid anions ( $\sim 5 \mu \mathrm{eq} \mathrm{l}^{-1}$ according to the model by Oliver et al., 1983). Both $\mathrm{pH}$ and lake water alkalinity rapidly declined in the 1950s after one century of moderate declines, and reached their minima in the 1980s (Fig. 4). Significant acidification, leading to a depletion of the carbonate buffering system, occurred in VW, DS, and ST. During the 1990s, the carbonate buffering system was re-established in all acidified lakes, and $\mathrm{pH}$ in VW and DS nearly reached their pre-acidification values (Fig. 4). Compared to the currently observed Gran alkalinity in the lakes, the model predicts lower concentrations. This disproportion is in part due to the uncertainty in prediction of $\mathrm{NO}_{3}^{-}$concentrations.

The modelled concentrations of ionic aluminium forms $\left(\mathrm{Al}_{\mathrm{i}}{ }^{\mathrm{n}+}\right)$ were $<1 \mu$ eq $\mathrm{l}^{-1}$ before 1950 and reached their maximum (16 and $26 \mu \mathrm{eq} \mathrm{l}^{-1}$ in DS and ST, respectively) in the middle $1980 \mathrm{~s}$. The current $\mathrm{Al}_{\mathrm{i}}{ }^{\mathrm{n}+}$ concentrations have declined to $<1 \mu$ eq $1^{-1}$ in all but ST Lake $\left(4 \mu \mathrm{eq} 1^{-1}\right)$. The simulated and observed molar concentrations of total (ionic and organically bound) Al are given for DS and ST Lakes in Fig. 5. Even in these two lakes, which were most severely acidified in the $1980 \mathrm{~s}$, concentrations of total Al will decline $<1.3 \mu \mathrm{mol} \mathrm{l}^{-1}$ by 2010 , which is a most promising pattern regarding the future biological recovery of the acidified Tatra lakes.

The chemical trends given in Figs. 3-5 can be divided into three periods: (1) acidification progress (1860 to 1980s), (2) acidification retreat (1980s to 2010), and (3) future prediction (2010-2050), which is uncertain due to uncertainty 

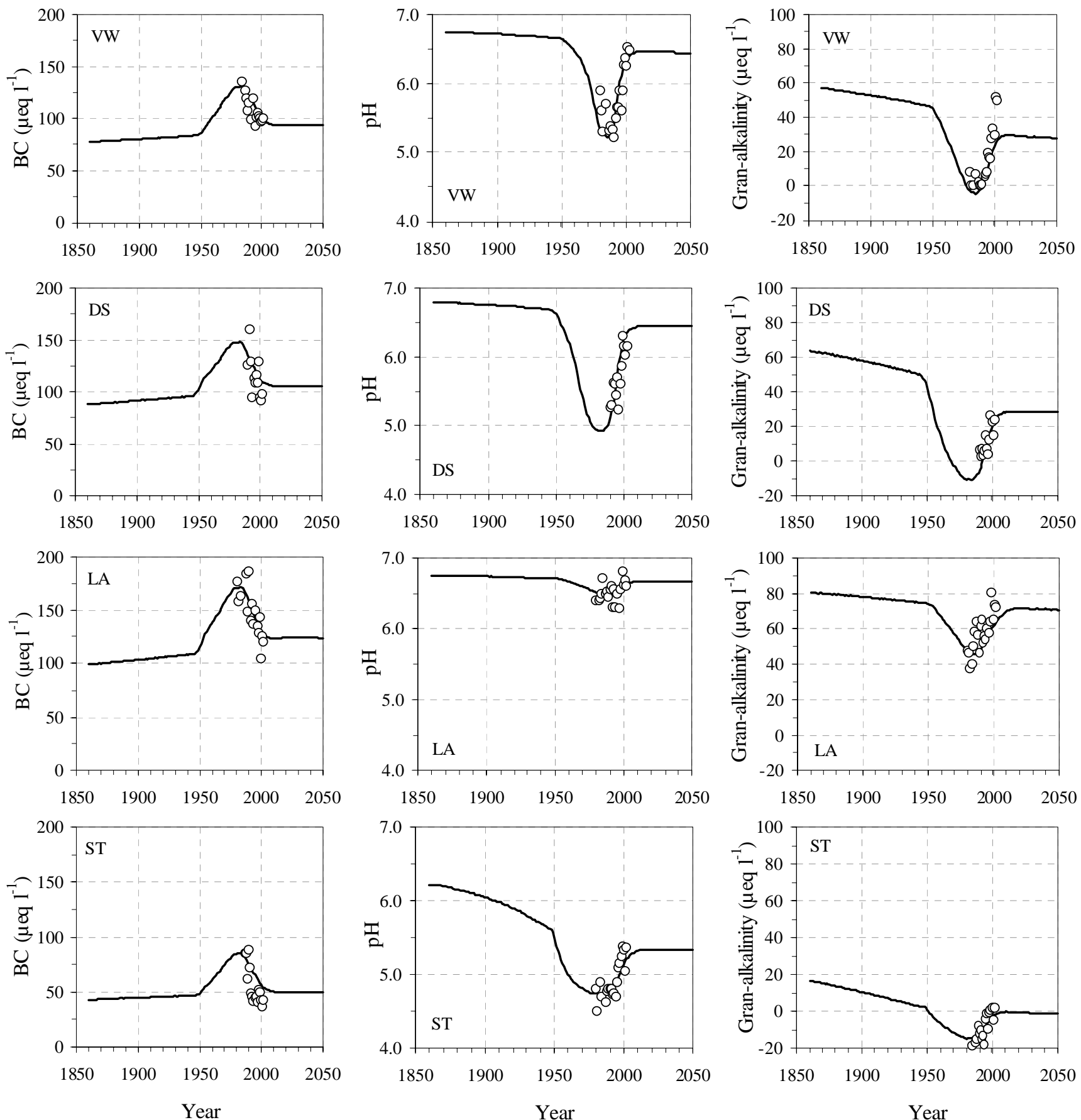

Fig. 4. Measured (open circles) and modelled (line; MAGIC 7) trends in concentrations of base cations (BC), pH and Gran alkalinity in alpine lakes in the Tatra Mountains. Forecast is based on quality of atmospheric deposition presupposed by the Gothenburg Protocol (UNECE, 1999). For lake abbreviations see legend to Table 1.

associated with the fate of $\mathrm{N}$ cycling in the ecosystem. The first and second periods were characterised by significant changes in the concentration of strong acid anions (SAA = $\mathrm{SO}_{4}{ }^{2-}+\mathrm{NO}_{3}^{--}+\mathrm{Cl}^{-}$), which increased and then decreased by $107-149$ and 73-96 $\mu$ eq $\mathrm{l}^{-1}$, respectively. Both of these changes were compensated for by inverse changes in $\mathrm{HCO}_{3}^{-}$ concentrations and parallel trends in $\mathrm{BC}, \mathrm{H}^{+}$, and $\mathrm{Al}_{\mathrm{i}}^{\mathrm{n}}{ }^{\mathrm{n}}$ concentrations (Fig. 6). Changes in $\mathrm{BC}$ concentrations were the most pronounced process, compensating for $40-70 \%$ of the changes in SAA (Fig. 7). From one to two thirds of these changes were associated with trends in deposition chemistry (Fig. 6) and the rest with the terrestrial export of BC. The 

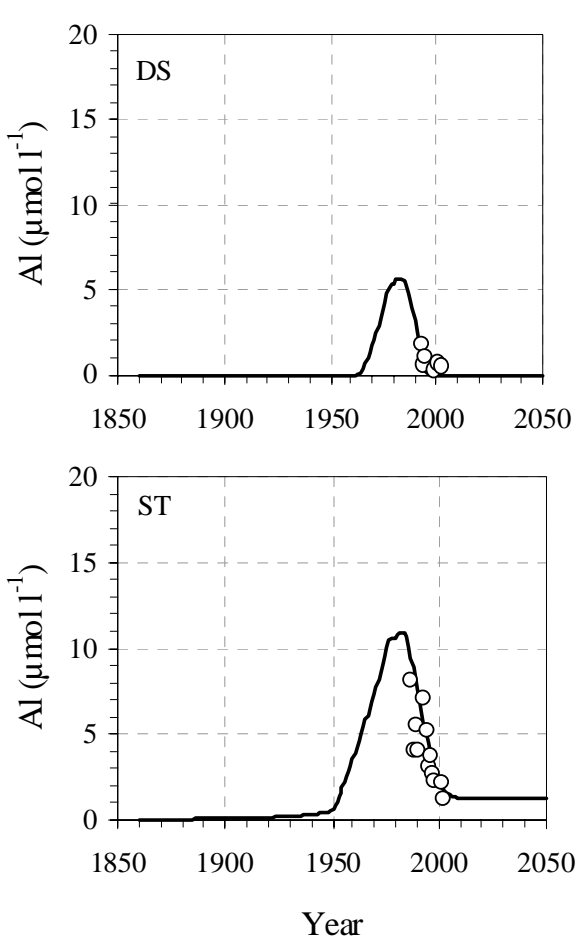

Fig. 5. Measured (open circles) and modelled (line; MAGIC 7) trends in concentrations of total aluminium in Dlugi Sraw (DS) and Starolesnianske Lake (ST) in the Tatra Mountains. Forecast is based on quality of atmospheric deposition presupposed by the Gothenburg Protocol (UN-ECE, 1999).
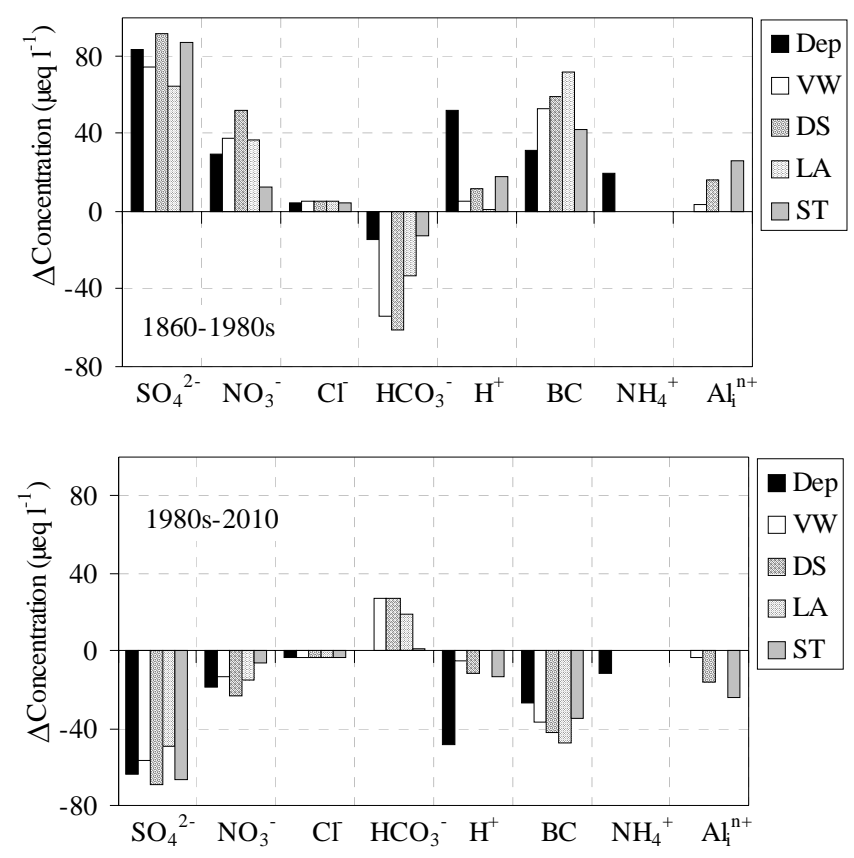

Fig. 6. Changes in composition of atmospheric deposition (Dep) and lake water during the period of acidification progress (18601980s) and retreat (1980s-2010) as simulated by MAGIC 7 for the alpine Tatra lakes. For lake abbreviations see legend to Table 1.
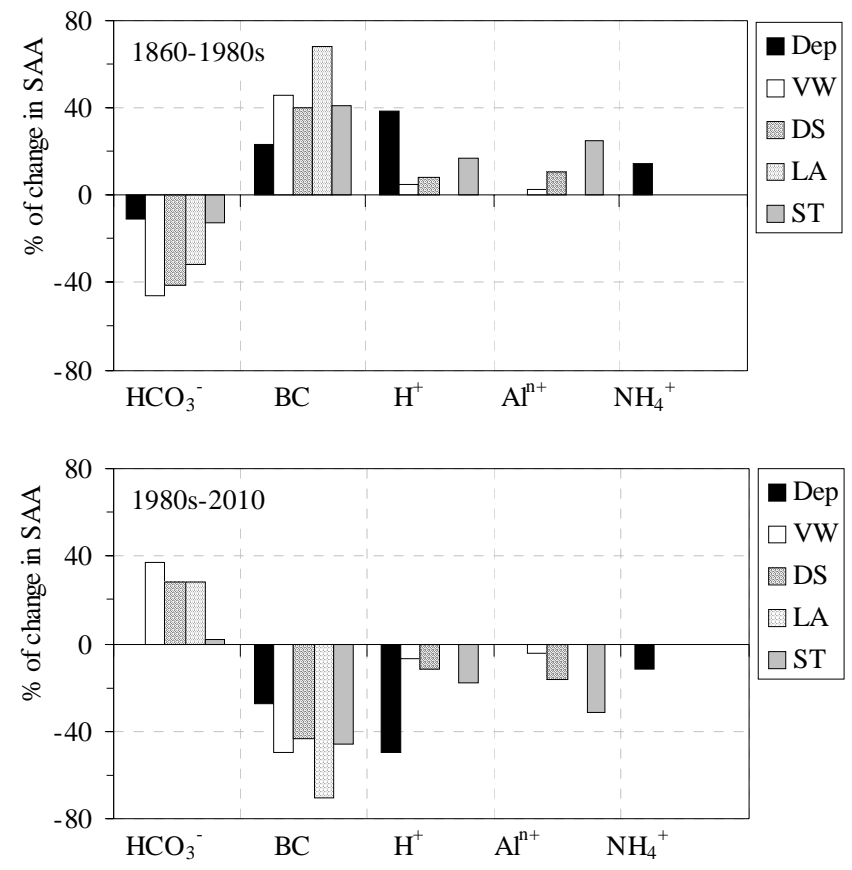

Fig. 7. Relative importance of changes in chemistry of atmospheric deposition (Dep) and lake water, compensating changes in concentrations of strong acid anions (SAA) during the period of acidification progress (1860-1980s) and retreat (1980s-2010). Data were simulated by MAGIC 7 for the alpine Tatra lakes. For lake abbreviations see legend to Table 1.

latter process exhibited tight links to the base saturation of soils, being as expected most pronounced in the LA catchment and lowest in the ST catchment with the highest $(20 \%)$ and lowest ( $8 \%$ ) base saturations, respectively (Table 1).

The modelled decline in lake water concentrations of $\mathrm{HCO}_{3}^{-}$was $13-62 \mu \mathrm{eq} \mathrm{l}^{-1}$ during the period of acidification progress (Fig. 6) and compensated for $13-47 \%$ of the increase in SAA (Fig. 7). These modelled results show that the decline in alkalinity of the Tatra lakes was $\sim 50 \%$ lower than expected in former papers (Kopácek and Stuchlík, 1994; Kopácek et al., 2000), which were based on the observed data only. In contrast to the reliable historical data on $\mathrm{SO}_{4}{ }^{2-}$ and $\mathrm{NO}_{3}{ }^{-}$concentrations in the Tatra lakes (Stangenberg, 1938), no reliable data are available for $\mathrm{HCO}_{3}{ }^{-}$and $\mathrm{BC}$ concentrations before the $1980 \mathrm{~s}$. Hence, the simple estimation of pre-acidification alkalinity, based on the measured (in the 1980s) concentrations of $\mathrm{HCO}_{3}^{-}, \mathrm{H}^{+}$and $\mathrm{Al}$, and historical changes in concentrations of $\mathrm{SO}_{4}{ }^{2-}$ and $\mathrm{NO}_{3}{ }^{-}$but which neglected changes in BC concentrations, resulted in higher values than the current MAGIC simulation. 


\section{TRENDS IN SOIL CHEMISTRY}

The modelled pre-acidification soil base saturation was highest (32\%) in LA Lake and lowest (9\%) in ST Lake (Fig. 8). Similarly, loss of BC from the soil cation-exchange sites was most pronounced in the LA catchment, monotonous in the VW and DS catchments and almost stable in the ST catchment. Accumulation of $\mathrm{BC}$ in the soils during the period of decreasing $\mathrm{S}$ and $\mathrm{N}$ deposition (from the late 1980s to 2010) was significant only in the LA catchment (Fig. 8), which had the highest overall weathering rates (Table 4). Similarly, the 'Gothenburg' scenario of the future emission rates of $\mathrm{S}$ and $\mathrm{N}$ compounds in central Europe suggested a partial recovery of soil base saturation only in the LA catchment. Even in 2050, however, base saturation of the LA soils will be $\sim 30 \%$ lower than its pre-acidification level. Analogous predictions for other catchments exhibited no increase in the soil base saturation, suggesting that current and future changes in the quality of atmospheric deposition can stop the depletion of their exchangeable BC pools but cannot be sufficient for their recovery.

Such a scenario is not surprising in areas of bedrock with low weathering rates. In addition to the declines in atmospheric deposition of SAA, deposition of base cations declined significantly in Europe due to the control of pointsources of particulate matter such as fly ash (Hedin et al., 1994). These measures led to $>90 \%$ lowered emission of particulates in the area of Czech Republic and Slovakia in the 1985-2000 period (Kopácek et al., 2002). The current atmospheric deposition of $\mathrm{BC}$ is thus based more on agricultural and transportation sources than on industrial sources and will probably not increase significantly without e.g. climate change towards drier and more windy weather. The observed differences in the base saturation of soils were in contrast to comparable composition of dominant bedrock in all catchments studied. However, the complexity of the Tatra Mountain geology does not exclude the possibility of small amounts of rapidly weathering rocks (either chemically or due to a larger surface area of more finely crumbled rocks).

\section{Conclusions}

The MAGIC 7 simulation of the chemistry of four alpine Tatra lakes exhibits gradual water acidification in the 1860 1950 period, significant changes during the period of strongest acidification (1950 to 1980s) and its retreat (1980s to 2010), and adjustment to steady-state conditions for the
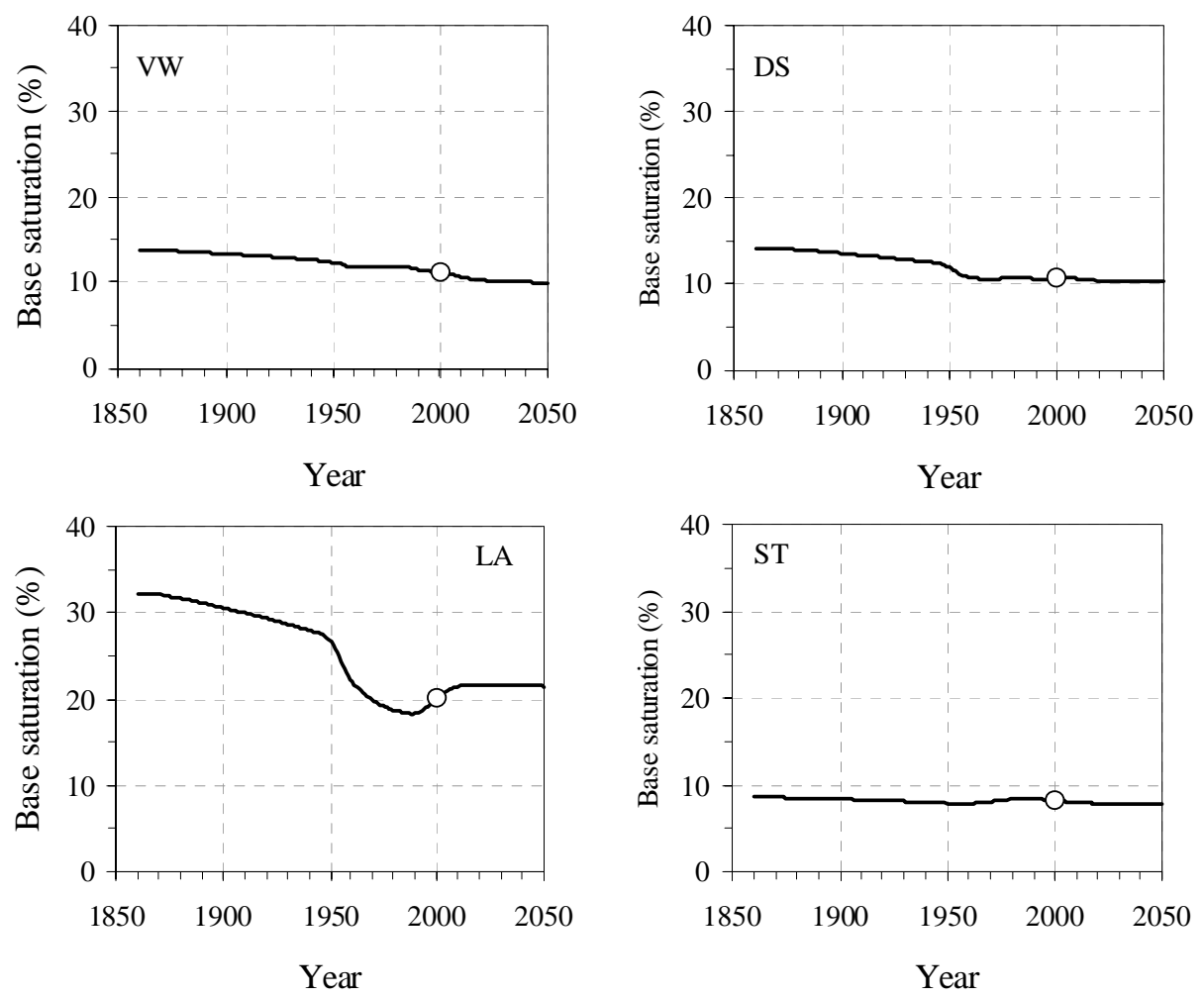

Fig. 8. Measured (open circles) and modelled (lines; MAGIC 7) trends in base saturation of soils in catchments of the alpine Tatra lakes. Forecast is based on quality of atmospheric deposition presupposed by the Gothenburg Protocol (UN-ECE, 1999). For lake abbreviations see legend to Table 1. 
2010-2050 period. While the measured trends in $\mathrm{pH}$, Gran alkalinity, $\mathrm{SO}_{4}^{2-}, \mathrm{Cl}^{-}, \mathrm{Al}$ and $\mathrm{BC}$ concentrations were reasonably simulated by the MAGIC 7 model, simulations of $\mathrm{NO}_{3}{ }^{-}$were more complex. Trends in atmospheric deposition of DIN and changes in soil C:N ratios were not sufficient to explain the observed changes in lake water concentrations of $\mathrm{NO}_{3}^{-}$without an additional assumption regarding changes in ecosystem ability to retain nitrogen. The model predicts the increasing importance of $\mathrm{NO}_{3}^{-}$, which will become the dominant anion in rocky lakes (VW and DS). Future climatically- or chemically-derived changes in soil $\mathrm{N}$-cycling can have a significant impact on $\mathrm{NO}_{3}^{-}$leaching and the total concentration of SAA (especially in these two lakes), and bias the modelled prognosis on lake water composition (see also Norton and Veselý, 2003). Consequently, the processes governing $\mathrm{N}$-dynamics in similar ecosystems should be examined in further studies.

According to the forecast based on the Gothenburg Protocol (UN-ECE, 1999), the carbonate buffering system will be re-established, and Gran alkalinity and $\mathrm{pH}$ will come back to their 1950s and early 1960s levels, respectively. In the three lakes situated in rocky catchments, Gran alkalinity and $\mathrm{pH}$ will increase to $28-71 \mu \mathrm{eq} 1^{-1}$ and 6.4-6.7, respectively, after 2010. Only ST Lake, with the highest proportion of alpine meadows in the catchment among alpine Tatra lakes, will remain affected by acidification ( $\mathrm{pH}$ of 5.3 and Gran alkalinity of $0-2 \mu$ eq $1^{-1}$ ).

Questions have arisen regarding the potential biological recovery of the Tatra lakes, similarly to other areas recovering from strong acidification (e.g. Sudbury area lakes; Keller and Yan, 1991; Shartau et. al., 2001). It is expected that biological recovery will lag considerably behind the chemical reversal rates due to many external and internal, abiotic and biotic factors that affect the biological recovery rates of damaged lakes (e.g. Keller and Gunn, 1995; Snucins et al., 2001).

Major changes in zooplankton communities in the Tatra lakes occurred likely between 1975 and 1978 (Stuchlik et al., 1985; Fott et al., 1994). Analysis of zooplankton species composition in the 1980s showed: (1) no changes in lakes with $\mathrm{pH}>6$ and $\mathrm{ANC}>25 \mathrm{meq} \mathrm{1}^{-1}$, (2) extinction of zooplankton in lakes with $\mathrm{pH}$ between 5 and 6 and ANC between 0 and $25 \mu$ eq $1^{-1}$, and (3) extinction of the original species and their replacement by low numbers of low-pH tolerant species in lakes with $\mathrm{pH}<5$ and ANC $<0 \mu$ eq $\mathrm{l}^{-1}$ (Stuchlik et al., 1985, 2002). According to this classification, the ongoing chemical improvement of water should be sufficient for biological recovery of most Tatra lakes, even though the pre-industrial ANC will be barely reached due to the limited future recovery of soil base saturation.

\section{Acknowledgements}

The primary data on soil, water, and deposition chemistry were collected within projects supported by AL:PE II (EC program EV5V-CT92-0205; PECO), MOLAR (EU Environment and Climate Program; ENV4-CT95-0007), EMERGE (Environment Project of European Commission; EVK1-CT-1999-00032), Institutional Research Plan ASCR No. Z 6017912, and MSM 123100004, and were evaluated within RECOVER:2010 project (Environment Project of European Commission; EVK1-CT-1999-00018).

\section{References}

Alewell C., 1998. Investigating sulphate sorption and desorption of acid forest soils with special consideration of soil structure. Z. Pflanzenernähr. Bodenk., 161,161 73-80.

Berge, E., 1997. Transboundary air pollution in Europe, Part 1, EMEP MSC-W Report 1/97, Norwegian Meteorological Institute, Oslo, Norway. 108pp .

Chomitz, K. and Samaj, F., 1974. Zrážkové pomery (Precipitation). In: Klima Tatier, M. Koncek et al. (Eds.), VEDA, Bratislava, (in Slovak). 443-536.

Cosby, B.J., Ferrier, R.C., Jenkins, A. and Wright R.F., 2001. Modelling the effects of acid deposition: refinements, adjustments and inclusion of nitrogen dynamics in the MAGIC model. Hydrol. Earth Syst. Sci., 5, 499-517.

Curtis, C.J., Allott, T.E.H., Reynolds, B. and Harriman, R., 1998. The prediction of nitrate leaching with the first-order acidity balance (FAB) model for upland catchment in Great Britain. Water Air Soil Pollut., 105, 205-215.

Driscoll, C.T., 1984. A procedure for the fractionation of aqueous aluminum in dilute acidic waters. Int. J. Environ. Anal. Chem., 16, 267-284.

Fott, J., Pražáková, M., Stuchlík, E. and Stuchlíková, Z., 1994. Acidification of lakes in 'umava (Bohemia) and in the High Tatra Mountains (Slovakia). Hydrobiologia, 274, 37-47.

Glatzel, G., 1991. The impact of historic land use and modern forestry on nutrient relations of Central European forest ecosystems. Fertilizer Res., 27, 1-8.

Gundersen, P., Callesen, I. and de Vries, W., 1998a. Nitrate leaching in forest ecosystems is related to forest floor $\mathrm{C} / \mathrm{N}$ ratios. Environ. Pollut., 102, 403-407.

Gundersen, P., Emmett, B.A., Kjonaas, O.J., Koopmans, C.J. and Tietema, A., 1998b. Impact of nitrogen deposition on nitrogen cycling in forests: a synthesis of NITREX data. Forest Ecol. Manage., 71, 143-151.

Hedin, L.O., Granat, L., Likens, G.E., Buishand, T.A., Galloway, J.N., Butler, T.J. and Rodhe, H., 1994. Steep declines in atmospheric base cations in regions of Europe and North America. Nature, 367, 351-354.

Henriksen, A., Mill, W. A., Kot, M., Rzychon, D. and Wathne, B.M., 1992. Critical loads of acidity to surface waters: A case study from the Polish Tatra Mountains. Report 29/1992, NIVA, Oslo, Norway. 34 pp.

Hruška, J., Moldan, F. and Krám, P., 2002. Recovery from acidification in central Europe - observed and predicted changes of soil and streamwater chemistry in the Lysina catchment, Czech Republic. Environ. Pollut. 120, 261-274.

Keller, W. and Yan, N.D., 1991. Recovery of crustacean zooplankton species richness in Sudbury area lakes following water quality improvements. Can. J. Fisheries Aquat. Sci., 48, 16351644. 
Keller, W. and Gunn, J.M., 1995. Lake water quality improvements and recovering aquatic communities. In: Restoration and Recovery of an Industrial Region, J.M. Gunn (Ed.), Springer, New York, USA. 69-80.

Kelly, C.A., Rudd, J.W.M., Hesslein, R.H., Schindler, D.W., Dillon, P.J., Driscoll, C.T., Gherini, S.A. and Hecky, R.E., 1987. Prediction of biological acid neutralisation in acid-sensitive lakes. Biogeochemistry, 3, 129-140.

Kopácek, J. and Stuchlík, E., 1994. Chemical characteristics of lakes in the High Tatra Mountains, Czechoslovakia. Hydrobiologia, 274, 49-56.

Kopácek, J., Stuchlík, E., Vyhnálek, V. and Závodský, D.,1996. Concentration of nutrients in selected lakes in the High Tatra Mountains, Slovakia: Effect of season and watershed. Hydrobiologia 319, 47-55.

Kopácek, J., Hejzlar, J., Stuchlík, E., Fott, J. and Veselý, J., 1998. Reversibility of acidification of mountain lakes after reduction in nitrogen and sulphur emissions in Central Europe. Limnol. Oceanogr., 43, 357-361.

Kopácek, J., Stuchlík, E., Straškrabová, V. and Pšenáková, P., 2000. Factors governing nutrient status of mountain lakes in the Tatra Mountains. Freshwater Biology, 43, 369-383.

Kopácek, J., Veselý, J. and Stuchlík, E., 2001a. Sulphur and nitrogen fluxes and budgets in the Bohemian Forest and Tatra Mountains during the Industrial Revolution (1850-2000). Hydrol. Earth System Sci., 5, 391-405.

Kopácek, J., Ulrich, K.-U., Hejzlar, J., Borovec, J. and Stuchlík, E., 2001b. Natural inactivation of phosphorus by aluminum in atmospherically acidified water bodies. Water Research, $\mathbf{3 5}$, 3783-3790.

Kopácek, J., Stuchlík, E., Veselý, J., Schaumburg, J., Anderson, I. C., Fott, J., Hejzlar, J. and Vrba, J., 2002. Hysteresis in reversal of Central European mountain lakes from atmospheric acidification, Water Air Soil Pollut.: Focus 2, 91-114.

Kopácek, J., Kana, J., Santrucková, H., Picek, T. and Stuchlík, E. Chemical and biochemical characteristics of alpine soils in the Tatra Mountains and their correlation with lake water quality. Water Air Soil Pollut., in press.

Lajczak, A., 1996. Hydrologia. In: Przyroda TatrzaDskiego Parku Narodowego, Z. Mirek, Z. Glowacinski, K. Klimek and H. Piekos-Mirkowa (Eds.), Tatrzanski Park Narodowy, ZakopaneKraków, (in Polish). 169-196.

Lydersen, E., Rzychon, D., Worsztynowicz, A., Torseth K., Hanssen, J.E., Mill, W.A., Kot, M., Henriksen, A. and Wathne, B.M., 1997. Critical loads of acidity to lakes in the Polish Tatra Mountains-Final report. Report 44/1997, NIVA, Oslo, 49 pp.

Majer, V., Cosby, B.J., Kopácek, J. and Veselý, J., 2003. Modelling Reversibility of Central European Mountain Lakes from Acidification: Part I - The Bohemian Forest. Hydrol. Earth Syst. Sci., 7, 494-509.

Norton, S.A. and Veselý, J., 2003. Acidification and Acid Rain. In: Environmental Geochemistry, B. Sherwood Lollar(Ed.), Vol. 9, Treatise on Geochemistry, Elsevier, N.Y. (in press).

Novák, M., Bottrell, S.H., Fottová, D., Buzek, F., Groscheová, H. and Žák, K., 1996. Sulphur isotope signals in forest soils of Central Europe along an air pollution gradient. Environ. Sci. Technol., 30, 3473-3476.

Oliver, B.G., Thurman, E.M. and Malcom, R.L., 1983. The contribution of humic substances to the acidity of colored natural waters. Geochim. Cosmochim. Acta. 47, 2031-2035.
Shartau, A.K.L., Walseng, B. and Snucins, E., 2001. Correlation between microcrustaceans and environmental variables along an acidification gradient in Sudbury, Canada. Water Air Soil Pollut., 130, 1325-1330.

Snucins, E., Gunn, J., Keller, B., Dixit, S., Hindar, A. and Henriksen, A., 2001. Effects of regional reductions in sulphur deposition on the chemical and biological recovery of lakes within Killarney Park, Ontario, Canada. Environ. Monit. Assess., 67, 179-194.

Sommaruga-Wögrath, S., Koinig, K.A., Schmidt, R., Sommaruga, R., Tessadri, R. and Psenner, R., 1997. Temperature effects on the acidity of remote alpine lakes. Nature, 387, 64-67.

Stangenberg, M., 1938. Zur Hydrochemie der Tatraseen. Verhandlungen der internationalen Vereinigung für theoretische und angewandte Limnologie, 8, 211-220.

Stuchlík, E., Stuchlíková, Z., Fott, J., Ružicka, L. and Vrba, J., 1985. Effect of acid precipitation on waters of the TANAP territory. Treatises concerning the Tatra National Park, 26, 173211. (In Czech, with English summary).

Stuchlík, E., Appleby, P., Bitušík, P., Curtis, C., Fott, J., Kopácek, J., Pražáková, M., Rose, N., Strunecký, O. and Wright, R.F., 2002. Reconstruction of long-term changes in lake water chemistry, zooplankton and benthos of a small, acidified highmountain lake: MAGIC modelling and palaeolimnological analysis, Water Air Soil Pollut.: Focus 2, 127-138.

The MOLAR Chemistry Group, 1999. The MOLAR project: atmospheric deposition and lake water chemistry. J. Limnol., 58, 88-106.

Torssander, P. and Mörth, C.-M., 1998. Sulphur dynamics in the Roof experiment at Lake Gardsjön deduced from sulphur and oxygen isotope ratios in sulphate. In: Experimental Reversal of Acid Rain Effects. The Gardsjön Roof Project, H. Hultberg and R. Skeffington (Eds.), Wiley, Chichester, UK. 185-206.

UN-ECE, 1999. Strategies and Policies for Air Pollution Abatement. Economic Commission for Europe (ECE.EB.AIR/ 65), Convention on Long-Range Transboundary Air Pollution, United Nations, New York and Geneva.

Veselý, J., Hruška, J., Norton, S.A. and Johnson, C.E., 1998a. Trends in water chemistry of acidified Bohemian lakes from 1984 to 1995: I. Major solutes. Water Air Soil Pollut., 108, 107-127.

Veselý, J., Hruška, J. and Norton, S.A., 1998b. Trends in the chemistry of acidified Bohemian lakes from 1984 to 1995: II. Trace elements and aluminum. Water Air Soil Pollut., 108, 425-443.

Vološcuk, I. (Ed.), 1994. Tatra National Park (Tatranský národný park). ISBN 80-901392-4-8, GRADUS, Slovakia. 551pp. (in Slovak).

Weber, R.O., Talkner, P., Auer, I., Böhm, R., Gaji-apka, M., Zaninovi, K., Brázdil, R. and Faško, P., 1997. 20 $0^{\text {th }}$-century changes of temperature in the mountain regions of central Europe. Climatic Change, 36, 327-344.

Zhou, L.M., Tucker, C.J., Kaufmann, R.K., Slayback, D., Shabanov, N.V. and Mynemi, R.B., 2001. Variations in northern vegetation activity inferred from satellite data of vegetation index during 1981 to 1999. J. Geophys. Res.-Atmos., 106, 2006920083. 